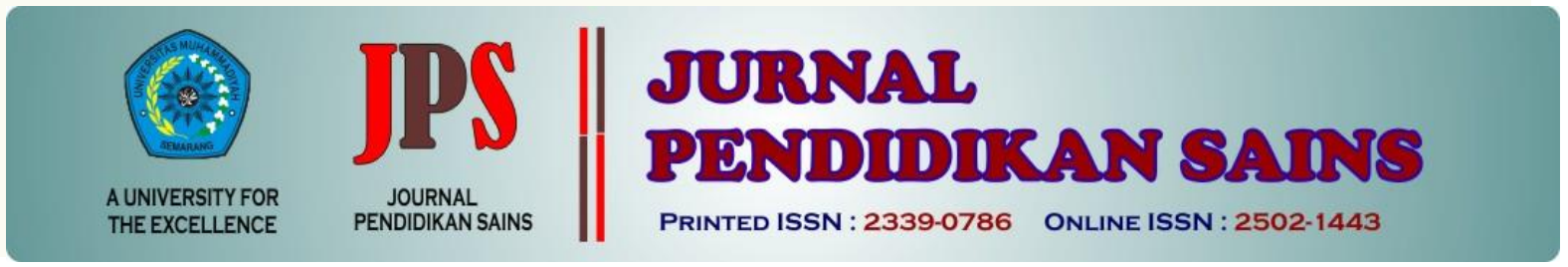

http://jurnal.unimus.ac.id/index.php/JPKIMIA

\title{
PENGEMBANGAN MEDIA PEMBELAJARAN DAMDAM JI CHEMISTRY PADA MATERI KOLOID UNTUK SMA/MA KELAS XI
}

\author{
Oleh: \\ ${ }^{1}$ Agus Kamaludin*, ${ }^{2}$ Desi Naurin Nisak \\ ${ }^{1,2}$ Universitas Islam Negeri Sunan Kalijaga Yogyakarta
}

\begin{tabular}{ll}
\hline Article history & Abstract \\
\hline $\begin{array}{l}\text { Submission }: 2020-02-04 \\
\text { Revised }\end{array}$ :2020-03-31 & $\begin{array}{l}\text { This study aimed to develop a Damdam Ji Chemistry learning media } \\
\text { on colloidal material. This research is Research \& Development } \\
\text { Accepted }: 2020-04-24\end{array}$ \\
(R\&D) which used the 4D development model (Define, Design, \\
Keyword: & $\begin{array}{l}\text { Development, and Disseminate). The instruments of data collection } \\
\text { consisted of media validation sheet, product quality assessment sheet, }\end{array}$ \\
and student response sheets. This product qulity was assessed by one \\
Kata kunci: traditional \\
games, damdam ji,
\end{tabular}$\quad \begin{aligned} & \text { material expert, one media expert, and three chemistry teachers. The } \\
& \text { result showed that the quality of the Damdam Ji Chemistry learning } \\
& \text { media have very good quality with an percentage ideal of 96,91\% } \\
& \text { from the chemistry teacher and have well postive response from the } \\
& \text { students with an percentage ideal of 93,2 \%. The use of Damdam Ji } \\
& \text { Chemistry in chemistry learning can make learning more interesting } \\
& \text { with games. }\end{aligned}$

\section{Pendahuluan}

Permainan tradisional merupakan suatu unsur kebudayaan yang memiliki ciri khas dan berasal dari nenek moyang yang disebarkan secara lisan, berbentuk tradisional, dan diwarisi secara turun menurun. Permainan tradisional sebagai aset budaya di Indonesia perlu dilestarikan guna mempertahankan eksistensinya di kalangan masyarakat. Perkembangan teknologi informasi dan komunikasi yang semakin pesat menyebabkan adanya modernisasi dalam segala bidang kehidupan (Qi, 2018). Pentingnya bangsa Indonesia memahami nilai budaya daerah berupa permainan tradisional dapat diwujudkan melalui bidang pendidikan yaitu penerapan permainan tradisional dalam proses pembelajaran.
Permainan tradisional memiliki peran edukasi bagi proses belajar seorang individu khususnya anak-anak (Irwanto, Aspilayani, Wahyuddin, 2014). Permainan tradisional dapat merangsang perkembangan anak dalam aspek motorik, kognitif, emosi, bahasa, sosial, spiritual, dan moral. Selain itu, permainan tradisional juga dapat meningkatkan motivasi beajar, minat belajar, dan menumbuhkan kepekaan peserta didik terhadap lingkungan sekitar (Azizah, 2016). Namun permainan tradisional sudah hampir punah dan tergeser oleh permainan modern seperti permainan dalam smartphone dan virtual game (Nur, 2013).

Pendidik yang memiliki peran penting dalam proses pembelajaran perlu menerapkan permainan tradisional dalam pembelajaran melalui media pembelajaran. Media $\begin{array}{ll}\text { *Corresponding Author: } \\ \text { Nama } & \text { : Agus Kamaludin } \\ \text { Lembaga } & : \text { Universitas Islam Negeri Sunan Kalijaga } \\ \text { Email } & : \text { aguskamaludin@gmail.com }\end{array}$ 
pembelajaran merupakan sarana atau alat bantu yang digunakan sebagai perantara dalam proses pembelajaran untuk meningkatkan efektivitas dan efisiensi dalam mencapai tujuan pembelajaran (Sanaky, 2013). Media pembelajaran sangat membantu pendidik dalam menyampaikan materi pembelajaran dengan lebih sederhana sehingga mudah dipahami oleh peserta didik (Batubara, 2015). Penggunaan media pembelajaran tidak hanya meningkatkan kualitas pembelajaran tetapi juga dapat menjadikan proses pembelajaran lebih menarik (Suyanti, 2010:82). Proses pembelajaran dengan menerapkan permainan dapat menjadikan peserta didik lebih aktif dan tertarik dalam mengikuti proses pembelajaran (Ulya \& Rahayu, 2017). Penerapan permainan dalam media pembelajaran mampu memberikan pengalaman langsung kepada peserta didik sehingga lebih mudah memahami konsep yang dipelajari dan tetap mengenal serta melestarikan kekayaan budaya (Ulya, 2017). Berdasarkan hasil penelitian menunjukkan bahwa media pembelajaran berbasis permainan tradisional yang diterapkan dalam pembelajaran mampu meningkatkan hasil belajar belajar dan motivasi belajar peserta didik (Azizah, 2016; Sukirno \& Ridwan, 2017; Dewi, Kurnia, \& Panjaitan, 2017).

Salah satu permainan tradisional yang dapat mengembangkan daya konsentrasi dan strategi pikir bagi pemainnya adalah permainan dam-daman. Permainan dam-daman merupakan permainan tradisional di Indonesia yang berasal dari Jawa dan hanya dapat dimainkan oleh dua orang pemain. Permainan ini dilakukan di atas papan yang memiliki pola khusus untuk permainan dam-daman dan memerlukan 16 butir biji untuk setiap pemain. Permainan itu hampir mirip dengan permainan catur, setiap pemain hanya boleh menjalankan biji damnya setelah pemain lain menyelesaikan langkahnya. Pemain harus berfikir dan menyusun strategi untuk menyerang daerah lawan dan menghabiskan biji dam lawan.

Pembelajaran kimia merupakan proses pembelajaran mengenai konsep kimia secara sistematis. Pembelajaran kimia menuntut peserta didik terlibat aktif dan berpartipasi secara langsung dalam pembelajaran sehingga konsep kimia dapat dipahami dengan mudah dan memenuhi standar kompetensi lulusan (Chairam, Klahan, \& Coll, 2015). Penelitian yang dilakukan oleh Lubis \& Ikhsan (2015) menunjukkan bahwa pembelajaran kimia cenderung kurang menyenangkan dan membosankan sehingga peserta didik mengalami kesulitan memahami materi kimia. Berdasarkan hasil UN tahun 2019 secara nasional pada materi kimia menunjukkan rerata skor kimia sebesar 50,99 (Kemendikbud, 2019). Rendahnya hasil belajar yang diperoleh perlu adanya solusi yang efektif untuk meningkatkan pemahaman peserta didik pada materi kimia. Salah satu materi kimia yang dianggap susah dipahami oleh peserta didik adalah materi koloid. Penelitian yang dilakukan oleh Wulandari, Marheni, \& Nurbaity (2014) menunjukkan bahwa beberapa peserta didik mengalami miskonsepsi pada beberapa konsep koloid diantaranya endapan pada suspensi, partikel mikroskopik, partikel terdispersi, Efek Tyndall, dan Gerak Brown.

Permainan tradisional yang dipadukan dengan media pembelajaran kimia di sekolah dapat melestarikan warisan kebudayaan bangsa Indonesia agar tidak punah. Adapun penelitian ini bertujuan untuk mengembangkan media pembelajaran Damdam Ji Chemistry dan menguji kelayakan media berdasarkan penilaian ahli, pendidik kimia, dan respon peserta didik.

\section{Metode Penelitian}

Jenis Penelitian

Jenis penelitian in merupakan penelitian pengembangan (Research and Development/R\&D). Model pengembangan dalam penelitian ini mengadaptasi model pengembangan 4-D yang terdiri dari empat Define, Design, Development dan Disseminate. Namun, penelitian ini tidak melakukan tahapan Disseminate (penyebarluasan).

Subjek Penelitian

Subjek penelitian dalam pengembangan media pembelajaran Damdam Ji Chemistry pada materi koloid dilakukan oleh dosen ahli yaitu satu dosen ahli materi dan satu dosen ahli media, dan pendidik kimia.

Prosedur

penelitian ini menggunakan model pengembangan 4D yang terdiri dari 4 tahapan yaitu Define, Design, Development, dan Disseminate. Penelitian pengembangan ini hanya dilakukan sampai tahap development saja tanpa disseminate. Tahap define (pendefinisian) dilakukan dengan pengumpulan data analisis kebutuhan melalui observasi langsung pembelajaran di kelas, analisis kurikulum 
terkait materi yang akan dimuat dalam media, dan identifikasi masalah melalui wawancara kepada pendidikan dan peserta didik. Tahap design (perancangan) dilakukan dengan perencanaan pembuatan media, penyusunan aturan permainan, kartu soal, kartu bonus, jawaban dan penyusunan instrumen penilaian media. Tahap development (pengembangan) dilakukan dengan validasi media Damdam Ji Chemistry kepada ahli media dan materi, penilaian kualitas media oleh pendidik kimia, dan respon peserta didik terhadap media yang dikembangkan.

Data, Intrumen, dan Teknik Pengumpulan Data

Data yang dikumpulkan dalam penelitian ini adalah data validasi ahli, data penilaian kualitas media, dan data respon peserta didik. Teknik pengumpulan data yang digunakan yaitu angket penilaian media. Instrumen penelitian terdiri dari lembar validasi media dan lembar penilaian media dengan skala Likert serta lembar respon peserta didik dengan skala Guttman. Lembar validasi media oleh ahli materi terdiri dari aspek materi, soal, dan bahasa. Lembar vaalidasi media oleh ahli media terdiri dari aspek kepraktisan dan keluwesan, tampilan, dan fungsi secara keseluruhan. Lembar penilaian kualitas media oleh pendidik terdiri dari aspek materi, soal, bahasa, kepraktisan dan keluwesan, tampilann, dan fungsi secara keseluruhan.

Teknik Analisis Data

Data hasil validasi media oleh ahli dan penilaian kualitas media oleh pendidik dianalisis dengan menghitung skor rata-rata untuk setiap aspek penilaian. Skor rata-rata dibandingkan dengan kategori kelayakan media dengan kriteria penilaian ideal menggunakan skala Likert. Respon peserta didik dianalisis menggunakan skala Guttman dengan skor tertinggi bernilai 1 dan skor terendah bernilai 0 . Kemudian data yang diperoleh dianalisis menggunakan rumus berikut:

$\%$ keidealan $=\frac{\text { skor rata }- \text { rata }}{\text { skor tertinggiideal }} \times 100 \%$

\section{Hasil Penelitian dan Pembahasan}

Pengembangan Media Damdam Ji pada Materi Koloid

Produk media pembelajaran yang dihasilkan adalah media damdam ji chemistry pada materi koloid. Media yang dikembangkan ini dapat dijadikan sebagai salah satu inovasi media pembelajan peserta didik kelas XI sesuai dengan kurikulum 2013. Pengembangan media mengadaptasi model pengembangan 4D (Define, Design, Development, and Dissaminate) yang dibatasi hanya sampai tahap development.

\section{Define (Pendefinisian)}

Tahap ini dilakukan dengan analisis kebutuhan melalui observasi langsung di kelas, analisis kurikulum, dan identifikasi masalah dalam proses pembelajaran melalui wawancara pendidik kimia dan peserta didik. Berdasarkan hasil analisis kebutuhan dan analisis kurikulum diperoleh hasil bahwa peserta didik merasa kesulitan untuk materi yang bersifat abstrak dan hafalan sehingga dibutuhkan media pembelajaran yang dapat membantu memudahkan peserta didik untuk memahami materi tersebut. Salah satu materi kimia yang bersifat abstrak dan banyak hafalan adalah koloid. Berdasarkan hasil wawancara pendidik kimia SMA menunjukkan bahwa media pembelajaran yang digunakan oleh pendidik masih berupa buku cetak dan power point sehingga peserta didik sering merasa bosan dalam memahami kimia. Selain itu, berdasarkan hasil wawancara dengan peserta didik menunjukkan bahwa beberapa materi kimia sulit dipahami oleh peserta didik karena objek yang dipelajari bersifat abstrak dan salah satunya adalah materi koloid.

\section{Design (Perencanaan)}

Tahap perancangan dilakukan dengan perancangan media pembelajaran damdam ji chemistry dan penyusunan instrumen penilaian media. Rancangan komponen yang dibutuhkan dalam media pembelajaran damdam ji chemistry terdiri dari (1) papan damdaman berukuran besar; (2) kartu dam yang berisi soal; (3) kartu bonus; (4) buku petunjuk permainan; (5) pion main.

\section{Development (Pengembangan)}

Tahap ini dilakukan dengan pengembangan media damdam ji chemistry dengan komponen utama sebagai berikut

1. Papan Permainan Damdam Ji Chemistry Papan permainan dirancang dalam bentuk papan main kotak dengan ukuran 40 × 50 $\mathrm{cm}$. Kotak permainan tersebut terdapat bidak permainan, peraturan permainan, petak kartu soal dan kartu bonus. Bentuk desain permainan dapat dilihat pada Gambar 1 dan Gambar 2. Penentuan 
pemenang dalam permainan adalah apabila salah satu pemain berhasil menyerang 3 pion dam lawan yang berada di daerah ekor (segitiga) atau salah satu pemain kehabisan pion main.

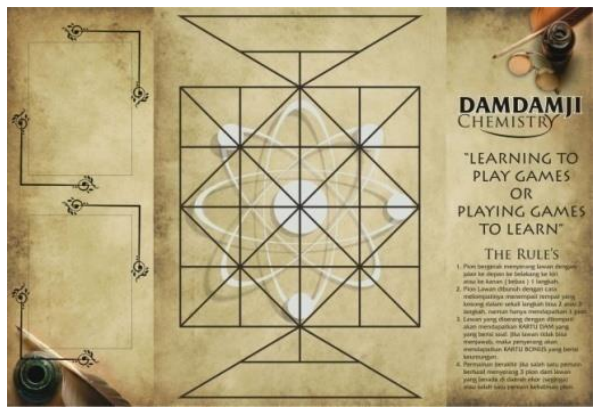

Gambar 1. Desain Papan Permainan Damdam Ji Chemistry dengan Desain 2-D

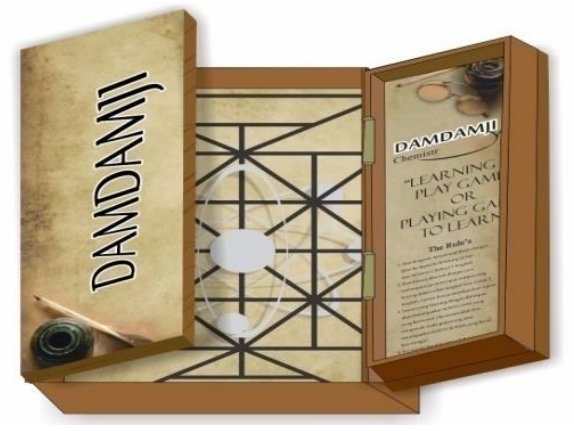

Gambar 2. Desain Papan Permainan Damdam Ji Chemistry dengan Desain 3-D

\section{Kartu Dam}

Kartu dam dibuat menggunakan program Corel Draw X4 dan dicetak dengan kertas ivory 260. Kartu dam berisi pertanyaanpertanyaan mengenai materi koloid. Pada saat bermain, lawan yang diserang dengan cara dilompati akan mendapatkan kartu dam. Jika lawan tidak dapat menjawab soal atau menjawab dengan jawaban salah maka penyerang akan mendapatkan kartu bonus. Kartu dam terdapat 40 pertanyaan dengan pertanyaan mengenai sistem koloid, jenisjenis koloid, sifat-sifat koloid, pembuatan koloid, dan koloid dalam kehidupan seharihari. Tampilan kartu dam tertera pada pada Gambar 3 dan Gambar 4.

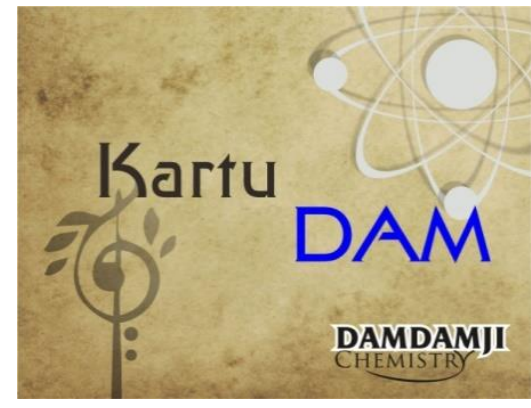

Gambar 3. Tampilan Kartu Dam dalam Media Damdam Ji Chemistry

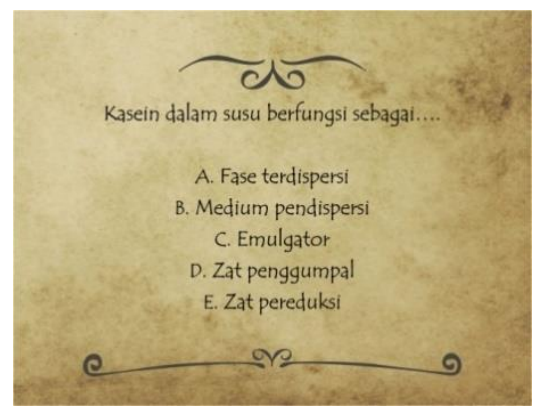

Gambar 4. Salah Satu Contoh Pertanyaan dalam Kartu Dam

3. Kartu Bonus

Kartu ini berisikan keuntungan yang bisa di dapat jika lawan yang diserang tidak dapat menjawab pertanyaan pada kartu dam. Tampilan kartu bonus dapat dilihat pada Gambar 5.

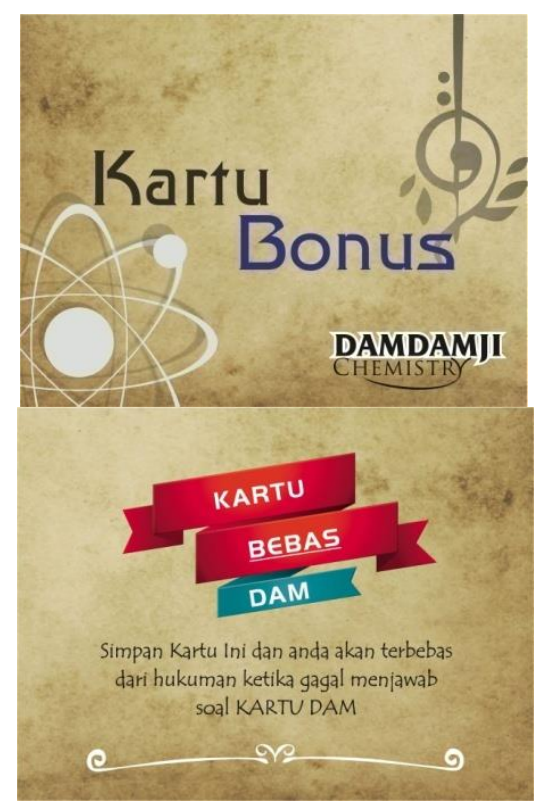

Gambar 5. Kartu Bonus Media Damdam Ji Chemistry

4. Poin Main

Pion ini disediakan sebanyak 30 buah dengan dua warna berbeda masing-masing 
15 buah. Tampilan pion main dapat dilihat pada Gambar 6.
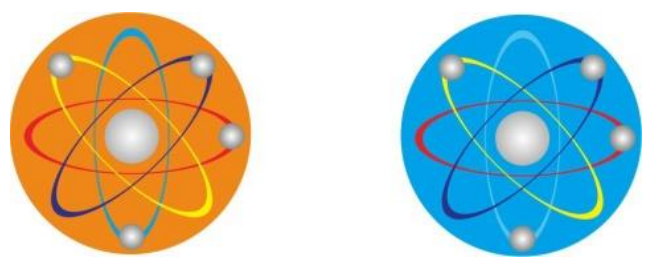

Gambar 6. Poin Main dalam Media Damdam Ji Chemistry

Penilaian Kualitas Media Damdam Ji Chemistry oleh Ahli Materi dan Ahli Media

Media pembelajaran Damdam Ji Chemistry pada materi koloid dinilai oleh satu dosen ahli materi dan satu dosen ahli media. Hasil penilaian kualitas media pembelajaran Damdam Ji Chemistry pada materi koloid dapat dilihat pada Tabel 2.

Tabel 2. Kualitas Media Damdam Ji Chemistry oleh Ahli Materi dan Ahli Media

\begin{tabular}{lcc}
\hline \multicolumn{1}{c}{ Aspek } & $\begin{array}{c}\text { Skor Ahli } \\
\text { Materi }\end{array}$ & $\begin{array}{c}\text { Skor Ahli } \\
\text { Media }\end{array}$ \\
\hline Materi & 14 & - \\
Soal & 14 & - \\
Bahasa & 14 & - \\
Kepraktisan dan & - & 22 \\
Keluwesan & - & 39 \\
Tampilan & - & 9 \\
Fungsi secara & - & 93 \\
Keseluruhan & & SB \\
Persenetase (\%) & 93 & SB \\
Kategori & SB & \\
\hline
\end{tabular}

Berdasarkan Tabel 2 penilaian media oleh ahli materi, pada aspek materi diperoleh skor sebesar 14; aspek soal diperoleh skor sebesar 14; aspek bahasa diperoleh skor sebesar 14 . Hasil penilaian media oleh ahli materi secara keseluruhan diperoleh persentase ideal sebesar 93\% dengan kategori Sangat Baik. Penilaian media oleh ahli media pada aspek kepraktisan dan keluwesan diperoleh skor sebesar 22; aspek tampilan sebesar 39; aspak fungsi secara keseluruhan sebesar 9. Hasil penilaian media oleh ahli media secara keseluruhan diperoleh persentase ideal sebesar 93\% dengan kategori Sangat Baik.

\section{Penilaian Media Damdam Ji Chemistry oleh Pendidik Kimia}

Media pembelajaran yang telah divalidasi oleh ahli materi dan ahli media selanjutnya dinilai oleh pendidik kimia dan direspon oleh pesert didik. Media damdam ji chemistry ini dinilai oleh 3 pendidik kimia dan direspon oleh 10 peserta didik. Hasil penilaian kualitas media oleh pendidik kimia dapat dilihat pada Tabel 3.

Tabel 3. Kualitas Media Damdam Ji Chemistry oleh Pendidik Kimia

\begin{tabular}{lc}
\hline \multicolumn{1}{c}{ Aspek } & Skor rerata \\
\hline Materi & 14,33 \\
Soal & 14,33 \\
Bahasa & 15,00 \\
Kepraktisan dan & 24,33 \\
Keluwesan & 38,33 \\
Tampilan & 10,00 \\
Fungsi secara & 96,91 \\
Keseluruhan & SB \\
Persentase (\%) & \\
Kategori &
\end{tabular}

Berdasarkan Tabel 3 penilaian media damdam ji chemistry oleh pendidik kimia secara keseluruhan pada aspek materi, soal, bahasa, kepraktisan dan keluwesan, tampilan, fungsi secara keseluruhan diperoleh persentase keidealan sebesar 96,91\% dengan kategori Sangat Baik. Media pembelajaran yang telah divalidasi oleh ahi materi dan ahli media serta dinilai oleh pendidik kimia selanjutnya dilakukan respon terhadap peserta didik. Hasil respon peserta didik terhadap media pembelajaran tertera pada Tabel 4. 
Tabel 4. Hasil Respon Peserta Didik terhadap Media Pembelajaran

\begin{tabular}{lcccc}
\hline \multicolumn{1}{c}{ Aspek } & $\begin{array}{c}\text { Skor } \\
\text { rerata }\end{array}$ & $\begin{array}{c}\text { Skor } \\
\text { maksimal }\end{array}$ & $\begin{array}{c}\text { Persentase } \\
\text { Keidealan } \\
(\boldsymbol{\%})\end{array}$ & Kategori \\
\hline Materi & 2 & 2 & 100,00 & SB \\
$\begin{array}{l}\text { Soal } \\
\text { Bahasa }\end{array}$ & 2,7 & 3 & 90,00 & SB \\
$\begin{array}{l}\text { Kepraktisan } \\
\text { dan }\end{array}$ & 2,8 & 3 & 93,33 & SB \\
$\begin{array}{l}\text { Keluwesan } \\
\text { Tampilan }\end{array}$ & 4,1 & 5 & 82,00 & SB \\
$\begin{array}{l}\text { Fungsi secara } \\
\text { Keseluruhan }\end{array}$ & 4 & 8 & 96,25 & SB \\
Total & 23,3 & 25 & 93,20 & SB \\
\hline
\end{tabular}

Berdasarkan Tabel 4 hasil analisis respon peserta didik setiap aspek memperoleh kategori sangat baik sehingga dapat disimpulkan bahwa media Damdam Ji Chemistry dapat digunakan sebagai media belajar sambil bermain bagi peserta didik. Kelebihan permainan Damdam Ji Chemistry ini diantaranya dapat dijadikan sebagai media pembelajaran yang efektif dan menyenangkan, tidak berbahaya, dapat dibawa dan digunakan dimana saja, serta tidak mudah rusak. Sedangkan sulit dimainkan dalam kelompok besar.

\section{Saran}

Media pembelajaran damdam ji chemistry yang telah dikembangkan perlu diuji coba secara luas kepada peserta didik untuk mengetahui pengaruh media pembelajaran dalam proses pembelajaran. Selain itu, peneliti lebih lanjut diharapkan untuk mengembangkan media berbasis permainan tradisional yang lebih menarik.

\section{Daftar Pustaka}

\section{Simpulan dan Saran}

Simpulan

Media pembelajaran yang dikembangkan dalam penelitian ini adalah media pembelajaran Damdam Ji Chemistry pada materi koloid. Media pembelajaran yang dikembangkan ini memiliki karakteristik sebagai berikut: (1) media cetak berupa papan berukuran $40 \mathrm{~cm}$ x $50 \mathrm{~cm}$ yang dilengkapi dengan peraturan permainan, kartu soal, kartu bonus, dan buku petunjuk permainan; (2) media dikembangkan dengan melakukan inovasi gabungan antara permainan tradisional dengan materi pembelajaran kimia; (3) media yang dikembangkan memperoleh kategori Sangat Baik dari penilaian ahli media, ahli materi, pendidik kimia, dan respon peserta didik. Hasil penilaian media Damdam Ji Chemistry oleh ahli materi, ahli media, pendidik kimia, dan respon peserta didik memperoleh persentase keidealan berturutturut sebesar 93\%, 93\%, 96,91\%, dan 93,20\% dengan kategori seluruhnya Sangat Baik (SB) sehingga media Damdam Ji Chemistry layak digunakan sebagai media pembelajaran bagi peserta didik.

Azizah, I. M. (2016). Efektifitas pembelajaran menggunakan permainan tradisional terhadap motivasi dan hasil belajar materi gaya di kelas IV MIN Ngronggot Nganjuk. Jurnal Dinamika Penelitian, 16(2), 279-308. DOI: 10.21274/dinamika.2016.16.2.27 9-308.

Batubara, H. H. (2015). Pengembangan media pembelajaran interaktif pada materi operasi bilangan bulat. MUALLIMUNA: Jurnal Madrasah Ibtidaiyah, 1(1), 1-12.

Chairam, S., Klahan, N., \& Coll, R. K. (2015). Exploring secondary students' understanding of chemical kinetics through inquiry-based learning activities. Eurasia Journal of Mathematics, Science \& Technology Education, 11(5), 937-956. DOI: 10.12973/eurasia.2015.1365a.

Dewi, T., Kurnia, D., \& Panjaitan, R. (2017). Penggunaan media permainan ular tangga pada pembelajaran PIPS untuk meningkatkan hasil belaajr siswa pada 
materi pembagian waktu di Indonesia. Jurnal Pena Ilmiah, 2(1), 2091-2100. DOI: $10.17509 / j p i . v 2 i 1.12425$.

Irwanto, Aspilayani, \& Wahyuddin. Implementasi media pembelajaran berbasis permainan tradisional dalam rangka pengembangan pendidikan dan karakter bangsa. Jurnal PENA, 1(1), 21-30.

Kemendikbud (2019). Kementrian Pendidikan dan Kebudayaan tahun 2013 tentang Laporan Hasil Ujian Nasional.

Lubis, I., \& Ikhsan, J. (2015). Pengembangan media pembelajaran kimia berbasis android untuk meningkatkan motivasi belajar dan prestasi kognitif peserta didik. Jurnal Inovasi Pendidikan IPA, 1(2), $191 \quad$ - 201. DOI :10.21831/jipi.v1i2.7504.

Nur, H. 2013. Membangun Karakter Anak Melalui Permainan Anak Tradisional. Jurnal Pendidikan Karakter, 3(1): 8794.

Qi, A. (2018). A Study of the Effect of Implementing Intellectual Property Education with Digital Teaching on Learning Motivation and Achievements. Eurasia Journal of Mathematics, Science and Technology Education, 4(6), 2445-2452. doi:10.29333/ejmste/89498.

Sanaky, H. A. (2013). Media pembelajaran interaktif-inovatif. Yogyakarta: Kaukaba Dipantara.

Sukirno \& Ridwan, D. (2017). Optimalisasi hasil belajar IPS melalui permainan tradisional. Jurnal Pendidikan Ilmu Pengetahuan Sosial Indonesia, 4(1), 22-37. DOI: https://doi.org/10.21831/jipsindo.v4i1. 14835 .

Suyanti, R. D. (2010). Strategi pembelajaran kimia. Yogyakarta: Graha Ilmu.

Ulya, H. (2017). Permainan tradisional sebagai media dalam pembelajaran matematika. Prosiding Seminar Nasional Pendidikan yang diselenggarakan oleh FKIP Universitas Muhammadiyah Metro, tanggal 12 Agustus 2017. Lampung: Universitas Muhammadiyah Metro.

Ulya, H. dan Rahayu, R. 2017. Pembelajaran Treffinger Berbantuan Permainan Tradisional Congklak untuk Meningkatkan Kemampuan Komunikasi Matematis. Jurnal Aksioma, 6(1): 48-55.

Wulandari, D. R., Marheni, Nurbaity. (2014). Analisis presepsi siswa pada materi koloid dalam pembelajaran kimia dengan menggunakan mental image analysis of students. Jurnal Riset Pendidikan Kimia, 4(1), 271-277. DOI: 10.21009/JRPK.041.07. 